AMERICAN

TRAJECTORIES 
By the Same Author

THE EXAMPLE OF MELVILLE

THE FERMENT OF REALISM

American Literature: 1884-1919

EDMUND WILSON

FICTIONS AND EVENTS

Essays in Criticism and Literary History

GREAT SHORT WORKS OF HERMAN MELVILLE, Ed.

A LITERATURE WITHOUT QUALITIES:

American Writing Since 1945

LITERATURE AND THE CONTINUANCES OF VIRTUE

HART CRANE: A Re-introduction 


\section{Warner Berthoff}
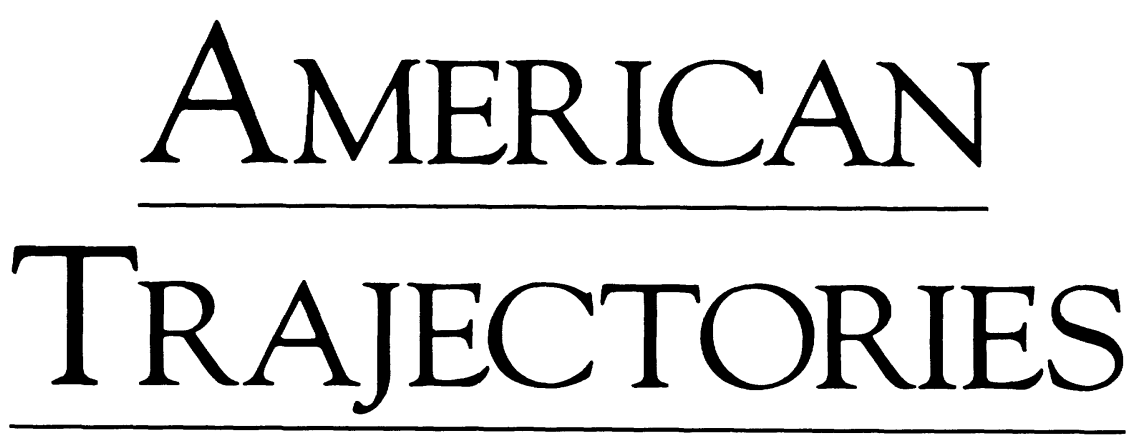

AUTHORS AND READINGS 1790-1970

The Pennsylvania State University Press

University Park, Pennsylvania 
Library of Congress Cataloging-in-Publication Data

Berthoff, Warner.

American trajectories : authors and readings, 1790-1970 / Warner Berthoff.

p. $\quad \mathrm{cm}$.

Includes index.

ISBN 0-271-01051-7 (alk. paper)

1. American literature-History and criticism. 2. United States -Civilization. I. Title.

PS121.B52 1994

$810.9-\mathrm{dc} 20$

$92-41208$

CIP

Copyright (C) 1994 The Pennsylvania State University

All rights reserved

Printed in the United States of America

Published by The Pennsylvania State University Press,

Barbara Building, Suite C, University Park, PA 16802-1003

It is the policy of The Pennsylvania State University Press to use acid-free paper for the first printing of all clothbound books. Publications on uncoated stock satisfy the minimum requirements of American National Standard for Information SciencesPermanence of Paper for Printed Library Materials, ANSI Z39.48-1984. 
For Tirzah and Rod 
This page intentionally left blank. 